\title{
PENGALAMAN DIGITAL KARYAWAN TERHADAP PENINGKATAN EFEKTIVITAS PERUSAHAAN PADA MASA PANDEMI COVID-19
}

Angelita Nauli Panggabean - 2301950881 - LB21

E-Business Strategy and Implementation

\begin{abstract}
Abstrak
Pandemi COVID-19 telah memberikan dampak bagi hampir seluruh perusahaan atau organisasi. Dengan begitu, banyak perusahaan telah menyadari bahwa agar dapat beradaptasi adalah dengan merangkul teknologi sebagai pendorong efektivitas perusahaan. Metode yang digunakan penulis adalah dengan mengumpulkan serta mempelajari jurnal-jurnal. Jurnal tersebut didapatkan dari berbagai sumber melalui internet. Dari jurnal-jurnal tersebut, dapat disimpulkan bahwa pengalaman digital karyawan merupakan unsur utama dalam mengatasi tantangan-tantangan tak terduga dalam meningkatkan efektivitas perusahaan, terutama pada masa pandemi COVID-19.
\end{abstract}

Kata Kunci: Pengalaman Digital Karyawan, Efektivitas Perusahaan

\section{Pendahuluan}

Pandemi COVID-19 ini, telah memberikan dampak pada hampir seluruh perusahan, sehingga menyebabkan perusahaan kesulitan dalam menjalankan bisnis serta cara berinteraksi dengan pekerja atau karyawannya. Dengan melihat dampak ini, perusahaan telah sadar bahwa agar mereka dapat menjadi tangkas dan merespons perubahan internal dan ekternal yang terjadi adalah dengan merangkul teknologi sebagai pendorong efektivitas perusahaan. Transformasi digital telah menjadi fokus perusahaan untuk memastikan keberlangsungan bisnis, terutama dengan sejumlah karyawan yang terpaksa harus bekerja dari rumah. Bekerja dari rumah atau Work From Home (WFH) bukanlah menjadi sesuatu yang asing lagi, terutama sejak pandemi COVID-19 yang mengharuskan untuk mematuhi kebijakan physical distancing sejak tahun 2020 awal. Namun, Work From Home (WFH) atau bekerja dari rumah ini tidak sepenuhnya dapat dilakukan oleh semua perusahaan, terutama bagi perusahaan yang masih menjalankan kegiatan bisnisnya secara konvensional dan juga memiliki keterbatasan pengalaman digital karyawannya. Dengan begitu, perusahaan harus dapat meningkatkan kelincahan perusahaan untuk dapat beradaptasi, mempertahankan efektivitas, serta tetap mendapatkan keuntungan yang optimal di tengah tantangan ini. Salah satu langkah penting yang dapat dilakukan adalah dengan cara merangkul strategi baru dan cara kerja yang lebih gesit untuk meningkatkan pengalaman digital kepada karyawan (Shambi, 2021), dan juga menjadikan kerja jarak jauh menjadi normal baru. Pengalaman dan kemampuan digital di tempat kerja merupakan faktor penting dan dibutuhkan untuk membantu perusahaan merespons perubahan yang dinamis demi dapat mencapai tujuan dan sasaran perusahaan. Oleh karena itu, telah membuat penulis tertarik untuk melihat hubungan pengalaman digital karyawan terhadap peningkatan efektivitas perusahaan. 


\section{Literature Review}

\section{Pengalaman Digital Karyawan}

Pengalaman kerja karyawan melibatkan beberapa faktor, diantaranya menemukan makna pekerjaan, berinteraksi, serta menanggapi kegiatan internal perusahaan (Hida Syahchari et al., n.d.). Pengalaman kerja karyawan telah berubah beberapa tahun terakhir, terutama diakibatkan oleh adanya perkembangan teknologi dan pekerjaan jarak jauh sehingga mengharuskan karyawan untuk memilki pengalaman teknologi digital. Teknologi digital dianggap sebagai alat utama bagi perusahaan dan organisasi dalam meningkatkan efektivitas dan kinerja (fauziah \& wahyuningtyas, 2020). Oleh karena itu, pengalaman digital karyawan sangat dibutuhkan perusahaan dan juga memiliki pengaruh yang signifikan terhadap peningkatan efektivitas perusahaan itu sendiri. Berdasarkan penelitian (Hida Syahchari et al., n.d.), pengalaman digital karyawan berpengaruh signifikan terhadap efektivitas perusahaan. Penelitian lain oleh M. Edmead melalui (Hida Syahchari et al., n.d.) juga menyebutkan bahwa pengalaman karyawan digital dapat menciptakan keunggulan kompetitif dan efektivitas. Faktanya, pengalaman digital karyawan yang baik akan membangun keterlibatan karyawan yang lebih besar, serta karyawan akan berkomitmen untuk membangun pengalaman yang baik untuk perusahaan secara keseluruhan. Dampak pandemi telah melahirkan konsep yang sudah tidak asing lagi bagi hampir semua karyawan, yaitu kerja jarak jauh atau sering dikenal kerja dari rumah (WFH). Kerja jarak jauh adalah dimana karyawan bekerja untuk perusahaan tanpa harus ke tempat kerja, tetapi mereka dapat bekerja dari rumah secara fleksibel. Konsep kerja jarak jauh inilah merupakan salah satu pengalaman kerja digital karyawan (Hida Syahchari et al., n.d.).

\section{Efektivitas Perusahaan}

Efektivitas perusahaan dapat diartikan sebagai tingkat kemampuan dan keberhasilan perusahaan atau organisasi dalam mencapai tujuan dan sasarannya. Dengan kata lain, perusahaan dapat dikatakan telah mencapai efektivitas apabila telah mencapai tujuan yang ditetapkan sebelumnya. Efektivitas perusahaan juga merupakan kemampuan perusahaan untuk bertahan, mencapai sasaran dan tujuan, serta mencukupi secara finansial (Hida Syahchari et al., n.d.). Efektivitas perusahaan sendiri dapat dipengaruhi oleh empat faktor, antara lain keterlibatan (involvement), adaptasi (adaptation), misi (mission), dan konsisten (consistency). Faktor pertama adalah keterlibatan, yaitu perlakuan yang membuat tenaga kerja merasa keikut sertaan atau terlibat dalam suatu perusahaan sehingga membuat mereka dapat bertanggung jawab dalam segala tindakan dan keputusannya. Faktor kedua adalah adaptasi, yakni diartikan sebagai kemampuan perusahaan dalam merespons pengaruh lingkungan eksternal dengan cara melakukan perubahan perusahaan internal. Sebagai contoh, pada masa pandemi COVID-19 ini dimana hampir semua perusahaan dituntut untuk mematuhi program pemerintah, salah satunya adalah bekerja dari rumah 
atau Work From Home (WFH). Dengan demikian, perusahaan secara keseluruhan harus mampu melakukan adaptasi, salah satunya dengan melakukan transformasi digital. Namun, masih terdapat tantangan dimana banyak tenaga kerja yang tidak mampu ataupun memiliki pengalaman menggunakan teknologi untuk melakukan pekerjaan di rumah. Sebagai contoh, karyawan perusahaan dituntut untuk dapat menggunakan online meeting platform saat melakukan pertemuan virtual. Faktanya, jika mereka tidak mengerti cara mengoperasikannya, kegiatan operasional perusahaan tidak akan berjalan sesuai dengan standar yang sudah ada dan dapat menuju pada penurunan efektivitas perusahaan. Faktor ketiga adalah misi, yakni sesuatu yang menunjukkan apa tujuan inti dari perusahaan sehingga dapat menjadikan pelaku usaha didalamnya menjadi focus, teguh, dan dapat mencapai tujuan. Dan faktor keempat adalah konsistensi, yaitu diartikan sebagai kesepakatan para pelaku usahan di suatu perusahaan terhadap nilai-nilai dan keyakinan inti perusahaan itu sendiri.

\section{Metode}

Karya tulis ini dibuat dengan metode literature review atau tinjauan pustaka, dimana penulis mengumpulkan dan mempelajari jurnal-jurnal. Jurnal tersebut didapatkan dari berbagai sumber melalui internet.

\section{Kesimpulan}

Pandemi COVID-19 yang tidak diketahui kapan usai, perusahaan perlu beradaptasi untuk untuk memastikan perusahaan berjalan dengan efektif. Karyawan harus terlibat dan juga mampu beradaptasi dengan perubahan, salah satunya pengunaan teknologi. Jika karyawan tidak mampu, maka kinerja dan efektivitas perusahaan akan menurun. Untuk asalan ini, pengalaman digital karyawan perlu berada diurutan teratas untuk setiap perusahaan atau organisasi. Dengan demikian, memberikan pengalaman pada karyawan merupakan unsur utama dalam mengatasi tantangantantangan tak terduga, dan juga untuk mencapai kesuksesan perusahaan. Dengan kata lain, pengalaman digital karyawan memiliki hubungan dan pengaruh yang signifikan terhadap efektivitas perusahaan.

\section{Reference:}

Fauziah, N. N., \& Wahyuningtyas, R. (2020). STUDI KASUS PADA PT. INDONESIA POWER UPJP KAMOJANG) Jurnal Mitra Manajemen (JMM Online. Nida Nur Fauziah, l(9), 1378-1392.

Hida Syahchari, D., Saroso, H., Sudrajat, D., Grace Herlina, M., \& W Jordaan, H. K. (n.d.). The Influence Of Digital Employee Experience And Employee Agility: Do They Boost Firm's Effectiveness? 
Shambi, J. (2021). Redefining Employee Experience during the Pandemic. Journal of Human Resource and Sustainability Studies, 09(03), 434-438.

https://doi.org/10.4236/jhrss.2021.93027 